\title{
Stock Market Reactions to the Comprehensive and Progressive Agreement for Trans-Pacific Partnership's Approval: Evidence from Vietnam
}

\author{
Son Tung $\mathrm{Ha}^{1+}$, Thi Hong Hanh Pham², and Thi Nguyet Anh Nguyen ${ }^{1}$ \\ ${ }^{1}$ National Economics University, Vietnam \\ ${ }^{2}$ University of Nantes, France
}

\begin{abstract}
We examine the stock market performance of Vietnam's listed firms in response to the country's approval of the Comprehensive and Progressive Agreement for Trans-Pacific Partnership (CPTPP). Employing an event study methodology, we first calculate the abnormal returns of all listed Vietnamese firms around the CРТPP's approval date. Then, we attempt to link these abnormal returns to firms' characteristics. We find evidence that the announcement of the CPTPP's approval is associated with positive abnormal returns for Vietnam's listed firms. We also find considerable heterogeneity in the magnitude and pace of the impacts of the CPTPP's approval on market returns across Vietnam's two stock exchanges. However, we fail to reject the null hypothesis that the market did not react to the CPTPP's approval at the sectoral level.
\end{abstract}

Keywords: Financial event study, Abnormal returns,

Comprehensive and Progressive Agreement for Trans-Pacific Partnership,

Vietnamese stock exchanges

JEL Classifications: G14, F13, F14

Received 7 January 2021, Revised 23 April 2021, Accepted 10 May 2021

\section{Introduction}

The number of regional trade agreements (RTAs) is growing, and these agreements are becoming increasingly complex. In 1990, only fifty trade agreements were in force, compared to more than 280 in 2017 (Hofmann et al., 2017). RTAs have become a key subject of many policy debates, and they are likely to shape trade and economic relations in the coming years. The impacts of RTAs on their member countries' welfare are also widely analyzed. In particular, several discussions focus on the impacts of the various new and deep trade agreements that

\footnotetext{
+Corresponding Author: Son Tung Ha

Faculty of Business Management, National Economics University, Hanoi, Vietnam. Add: 237 Giai Phong Road, Hai Ba Trung Dist, Hanoi, Vietnam. Tel: +84(0) 905666680. Email: hasontungneu@yahoo.com

Co-Author: Thi Hong Hanh Pham

HDR - LEMNA, IAE Nantes, University of Nantes, France. Add: Chemin de la Censive du Tertre, BP 52231, 44322

Nantes Cedex 3, France. Tel: +33 647962675, Fax: +33 24014 1749, Email: thi-hong-hanh.pham@univ-nantes.fr

Co-Author: Thi Nguyet Anh Nguyen

Faculty of Business Management, National Economics University, Hanoi, Vietnam. Add: 237 Giai Phong Road, Hai Ba Trung Dist, Hanoi, Vietnam. Tel: +32(0) 470082260. Email: anhnn27@gmail.com
} 
have been concluded or are being negotiated in developing countries. To complement the existing literature, this study empirically analyzes the impacts of the most recently concluded RTA, namely, the Comprehensive and Progressive Agreement for Trans-Pacific Partnership (CPTPP), using the lens of Vietnam's stock market.

On March 8, 2018, the CPTPP was signed by eleven countries1) in Chile. The agreement represents $13.5 \%$ of the global economy, or $\$ 10$ trillion in total, and $15 \%$ of global trade revenue, or $\$ 5$ trillion. The CPTPP focuses not only on reducing trade tariffs between its members but also on reducing non-tariff measures by easing existing regulations, making regulations more transparent, and reforming labor and environmental regulations. The agreement also includes an investor-state dispute settlement mechanism that allows firms to sue governments under certain conditions.

Maliszewska et al. (2018) estimate the economic and distributional impacts of the CPTPP for member and non-member countries using a global dynamic computable general equilibrium model. They compare the impacts of the CPTPP to a baseline scenario in which the CPTPP is not implemented. By 2030, CPTPP members' incomes are estimated to be $0.87 \%$ higher on average with the CPTPP than in the baseline scenario, with average losses for non-members of $0.03 \%$. In addition, the CPTPP is expected to help in lifting people out of poverty. Among the agreement's member countries, Vietnam, Malaysia, and Peru are expected to achieve the largest gains from the CРTPP. According to Maliszewska et al. (2018), the estimated income gains range from $0.13 \%$ for Mexico to $2.8 \%$ for Vietnam. In an alternative scenario that allows for productivity gains resulting from increased openness, the average income gains for CPTPP members range from $0.6 \%$ for Mexico to $4.4 \%$ for Vietnam by 2030.2) A World Bank estimation also suggests that Vietnam will benefit the most from the CPTPP's implementation. Sebastian Eckardt, the World Bank Lead Economist for Vietnam, said that the CPTPP "will bring direct benefits to Vietnam, from trade liberalization and improved market access. Most importantly, it will help stimulate and accelerate domestic reforms in many areas." The CPTPP is also expected to help promote transparency, support the creation of modern institutions in Vietnam, and stimulate reforms in such areas as competition, services, and so on.

For these reasons, empirically studying the reaction of Vietnam's economy to the CPTPP's approval seems to be relevant. However, evaluating the economic impacts of a trade agreement that has only been in effect for a few months is not easy. Instead of estimating the CPTPP's potential impacts, as Maliszewska et al. (2018) do, we investigate the response of Vietnam's stock markets to important news about the CPTPP's implementation. We assume that information

1) These countries are Australia, Brunei, Canada, Chile, Japan, Malaysia, Mexico, New Zealand, Peru, Singapore, and Vietnam.

2) The estimated gains are determined mainly by a combination of the assumed reduction in tariffs and non-tariff measures resulting from the CPTPP and the importance of the CPTPP members as trading partners. 
dissemination plays a key role in efficiently allocating resources across firms, which is fundamental to an economy's growth and development. More specifically, we evaluate the impacts of the CPTPP on Vietnam's economy by investigating the reactions of Vietnam's stock markets to the CPTPP's approval for two reasons. First, "security prices (or market[s]) [that] at any time 'fully reflect' available information [are] called efficient" (Fama, 1970, p. 383). In other words, new information that becomes available to financial markets is immediately reflected in current prices. The CPTPP's approval is important news. Some firms may be expected to benefit from this agreement, whereas others may suffer owing to the resulting lower trade barriers. In this case, a stock market index can capture the net effect on the expected future profits of a country's listed firms due to a RTA (Moser \& Rose, 2014). Second, Trefler (2004) argues that under trade liberalization, short-term adjustment costs have to be weighed against long-term gains. Overall, examining the impact of the CPTPP on Vietnam's stock markets allows us to understand whether the СРTPP brings direct economic benefits to Vietnam.

This study contributes to the existing literature in several ways. After over 30 years of the Doi Moi economic renewal campaign and the introduction of pro-business legislation, Vietnam now ranks as one of Asia's most attractive and popular destinations for foreign investors. The establishment of Vietnam's first stock exchange, the Ho Chi Minh Stock Exchange in 2002, also demonstrates the country's economic ambitions. Since its establishment, Vietnam's stock exchange has performed consistently strongly, and it now ranks among Asia's top bourses. Despite their remarkable development, however, Vietnam's stock exchanges have not attracted much attention from economic researchers. For instance, to date, no studies have empirically investigated the impacts of trade integration on Vietnam's stock exchanges. This study is therefore the first to address this issue by providing direct evidence of the reactions of Vietnam's stock exchanges to the СРТPP. This study also contributes to the literature on the impacts of trade policy changes on stock market valuations, which have mostly been investigated for developed countries (e.g., Breinlich, 2014; Ries, 1993). Lastly, our work builds upon important contributions to the literature regarding firm productivity and resource misallocation in emerging financial markets, such as that of Vietnam.

Our analysis is an event study of cumulative abnormal returns in the stock market. We use daily firm-level stock price data for all Vietnamese companies listed on the Ho Chi Minh and Hanoi Stock Exchanges during the period from June 2018 to March 2019. We analyze the event date of November 12, 2018, when the CPTPP was approved by Vietnam's National Assembly. First, we assess the reactions of Vietnam's stock markets to this news regarding the CPTPP's progress. Next, we extend our analysis to different sectors of economic activity to determine whether listed firms' responses to trade policy announcements vary by sector. Finally, we aim to link the impact of the CPTPP's approval on Vietnam's stock markets with the characteristics of listed firms. 
The reminder of this paper is organized as follows. Section 2 reviews the literature on stock markets' reactions to trade agreements. Section 3 outlines the main features of the CPTPP and its expected impacts on Vietnam's economy. Next, Section 4 describes the data and research methodology. Section 5 presents and discusses the main findings. We provide concluding remarks in Section 6.

\section{Stock Market Reactions to Free Trade Agreements}

In recent decades, many studies have investigated the economic effects of free trade agreements (FTAs). These studies typically use trade-related theories and data. According to Kawai and Wignaraja (2008), FTAs usually promote trade in goods and services and investments by improving the business environment for the involved trading partners. The impacts of FTAs on the real market lead to long- and short-term effects on financial markets as well. However, only a few empirical studies investigate the potential effects of FTAs on financial markets, particularly stock markets.

The existing empirical work on the relationship between FTAs and firms' financial performance is mainly based on Fama's (1970) efficient market hypothesis, which claims that markets are efficient in that security prices quickly adjust when new information (e.g., the approval of an FTA) arrives. Thompson $(1993,1994)$ investigates investors' expectations regarding the consequences of the Canada-United States Free Trade Agreement for manufacturing industries and firms in Canada. She argues that industry-level abnormal returns correspond only to the date when the agreement was reached in October 1987. A firm-level analysis shows that both comparative advantages and economies of scale play a role in determining investors' perceptions of the FTA's impacts.

Ghani and Haverty (1995) analyze the stock market's reaction to the passage of the North American Free Trade Agreement (NAFTA) for firms that cited NAFTA by applying the standard event study methodology. They find evidence of significant positive abnormal returns for these firms around the date when the United States House of Representatives approved NAFTA. They also argue that investors responded favorably to firms that were perceived to be major beneficiaries of NAFTA.

Rodriguez (2003) extends Thompson's $(1993,1994)$ work by studying investors' expectations of NAFTA's effect on the profitability of manufacturing industries in the United States, Canada, and Mexico. According to Rodriguez (2003), factor intensity, specifically represented by a measure of the industry-wide labor-capital ratio, is the most important determinant of excess returns. However, he finds no evidence of a relationship among profits, trade liberalization, and the relative scales of production of industries in NAFTA countries. Additionally, focusing 
on the FTA between the United States and Singapore, Parinduri and Thangavelu (2013) find that removing the last obstacle to free trade between the two countries increased the value of Singapore's traded firms in some industries by $1 \%$ to $11 \%$ on average.

Applying the dynamic industry model with heterogeneous firms developed by Melitz (2003)3), Breinlich (2016) investigates the stock market's reactions to the Canada-United States Free Trade Agreement of 1989 (CUSFTA). Using the uncertainty surrounding the CUSFTA's ratification, Breinlich (2016) shows that the pattern of Canadian manufacturing firms' abnormal returns is strongly consistent with predictions related to export (American) tariff reductions but is only weakly consistent with predictions related to import (Canadian) tariff reductions. Most recently, Dür and Lechner (2019) investigate the reactions of the shares of different types of firms to news on the lack of progress of negotiations that aimed to conclude the Transpacific Partnership (TPP) and the Transatlantic Trade and Investment Partnership. Using daily firm-level stock price data for nearly 4,000 companies in the United States over the period from 2009 to 2016, they find evidence that medium-sized companies benefit the most from trade agreements.

Whereas each of the above studies focuses on a specific FTA, Moser and Rose (2014) assess the effects of FTAs on stock returns using a large dataset that includes over 200 RTA announcements for 80 economies over 20 years. After adjusting these returns for international stock market movements, they evaluate the effects of news about RTAs on national stock market returns. These abnormal returns are then linked to features of the RTA members and the agreements themselves. Moser and Rose (2014) draw several important findings. First, they find supporting evidence for the natural trading partner hypothesis. Second, they find that stock returns rise more following the signing dates of RTAs between countries that already trade in high volumes. Third, stock returns also increase more when poorer countries sign RTAs and when RTAs are signed with smaller partners.

Some recent empirical studies also investigate the reactions of developing countries stock markets' to FTA approvals. Nezerwe and Karangwa (2018) examine the impact of the US-Morocco Free Trade Agreement, which intends to eliminate trade barriers between the two countries over 25 years. Using daily prices of the Moroccan All Shares Index on the Casablanca Stock Exchange, Nezerwe and Karangwa (2018) suggest that the FTA's implementation positively impacted stock returns in Morocco. Instead of studying the impacts of FTAs on stock returns, Qian and Diaz (2017) focus on the potential impact of trade integration on the short- and long-run volatility dynamics between Malaysia's stock market and 14 major developed and

3) Melitz's (2003) model adapts Hopenhayn's (1992) dynamic industry model for monopolistic competition in a general equilibrium setting and extends Krugman's (1980) trade model that incorporates firm-level productivity differences. On one hand, firms with different productivity levels can coexist in an industry because each firm faces initial uncertainty regarding its productivity before making irreversible investments to enter the industry. On the other hand, entry into an export market is also costly, but a firm decides whether to export after it learns about its productivity. 
developing stock markets in America, Europe, Africa, Asia and Oceania. They argue that most of the stock indices of Malaysia's major trading partners have significant spillover effects on its stock market. These spillover effects can be explained by the growing market integration between Malaysia and its trading partners.

Most recently, Crowley et al. (2019) examine the stock market performances of publicly listed Chinese firms in the solar panel industry in 2012 and 2013 in response to announcements of new import restrictions by the European Union and domestic policy changes within China. Using daily stock market prices from the Shanghai-Shenzhen, New York, and Hong Kong markets, they calculate abnormal returns following several policy changes affecting solar panels produced in China. Their main finding is consistent with Melitz's (2003) model, which argues that larger, more export-oriented firms experienced greater stock market losses following announcements of European trade restrictions. Melitz (2003) also suggests that European trade policy has a larger negative effect on Chinese firms in the private sector than on state-owned enterprises. Furthermore, firms listed in the United States are more responsive to news events than those listed in China and Hong Kong are.

Overall, only a few empirical studies go beyond estimating the impact of FTAs on stock market returns. To complement the existing literature, this study provides empirical evidence of the effects of one of the most recent FTAs, the CPTPP, on stock returns in Vietnam. More specifically, in the next sections, we examine the short-term linkage between international trade and Vietnam's stock markets by considering the stock market's reaction to news about the CPTPP's approval. According to Fama's (1970) efficient market hypothesis, a market is efficient if security prices adjust quickly when new information arrives. Thus, we expect that investigating stock market reactions can provide additional meaningful information about both efficiency and the real effects of the CPTPP on Vietnam's economy.

\section{Main Features of the CPTPP}

The CPTPP is an FTA between Australia, Brunei, Canada, Chile, Japan, Malaysia, Mexico, Peru, New Zealand, Singapore, and Vietnam. Following the Trump administration's decision to withdraw the United States from the TPP agreement, the eleven TPP parties entered into negotiations to implement the agreement largely as originally negotiated but without the United States. The CPTPP talks ended on January 23, 2018, and the agreement was signed on March 8, 2018, in Santiago, Chile. Essentially, the CPTPP Agreement was established and developed based on the TPP Agreement. The original TPP aspired to rewrite the ground rules for international commerce in the 21 st century, modeled on the economic governance regime of the United States. The CPTPP preserves the original text of the TPP that was agreed upon in October 
2016, but it suspends numerous provisions and leaves many specific issues to be resolved. The most significant revisions were to the investment and intellectual property chapters.

It is fair to say that becoming members of the CPTPP organization has greatly benefited the 11 participating countries. First, the CPTPP Agreement has opened up new market access for goods by eliminating the taxes and non-tariff barriers that often prevent imports from competing with domestically produced goods. It was expected that duties would be completely eliminated for a significant percentage of goods on the very first day of the agreement. For most of the remaining sensitive products, duties are to be reduced over time. Thus, exporters who faced significant duties in particular markets prior to the agreement gained the ability to lower their costs and easily export items abroad. Second, the CPTPP Agreement also supports an integrated Asia-Pacific marketplace. More specifically, unlike bilateral trade agreements, the СРТPP allows companies to manufacture products for all 11 markets without needing to change processes, parts, suppliers, or components. Once an item qualifies under the rules of origin for the СРTPP, it can be shipped from one CPTPP country to all 11 markets. These rules support integrated sourcing in line with modern production patterns in which parts and components are produced in multiple countries to be assembled and delivered to market. Third, the CPTPP is modernizing clearance and reducing costs at the border. Thus, this agreement has created new opportunities in services, such as banking, insurance, construction, logistics, accounting, and travel and tourism, among its member countries. Finally, the CPTPP provides protection for investments and guarantees to facilitate cross-border investments. It offers several different benefits, including intellectual property protection, digital economy expansion, and government contract opportunities.

However, uncertainty as to whether the CPTPP would obtain official approval from its 11 member countries persisted for some time, leading to doubt about which countries would sign the agreement. After United States President Donald Trump signed the order to withdraw from the TPP in January 2017, the agreement was muted, and doubts as to whether the CPTPP would be implemented arose. However, the remaining 11 country members ultimately agreed to move forward.

The TPP evolved into the weaker CPTPP after an almost farcical series of setbacks at the Asia-Pacific Economic Cooperation (APEC) Summit in Vietnam in 2017. Its future is still uncertain because the TPP11, named right after the withdrawal of the United States, was due to be signed in Da Nang. As an Asian developing country, Vietnam has clearly benefited from the CPTPP, which has required it to make important institutional reforms. Almost one year after the APEC summit in Da Nang, Australia, Brunei, Canada, Chile, Japan, Malaysia, Mexico, New Zealand, Peru, Singapore, and Vietnam signed the revised agreement in Chile on March 8, 2018. At that time, Vietnam's financial market predicted the upcoming change, but the official approval date had not been announced in the media. 
On November 12,2018 , the $14^{\text {th }}$ National Assembly passed a resolution approving all deals and related documents, and the CPTPP came into effect on January 14, 2019. This event was seen as an important milestone for Vietnam's economy. To ratify and implement the CPTPP, the Standing Committee of the National Assembly confirmed that its 265 laws and regulations (effective as of April 30, 2018) had been investigated by the Ministry of Justice and the government. The Standing Committee of the National Assembly also instructed the government to amend certain draft laws on anti-corruption, labor, crimes, criminal procedures, intellectual property, and insurance in line with Vietnam's commitments under the CPTPP. Nearly one month after the CPTPP's implementation, Prime Minister Nguyen Xuan Phuc approved a plan to implement the deal following specific steps. As of now, Vietnam's government has issued 15 legal documents related to the СРТPP and is still reviewing existing legislation to ensure that it is compatible with the deal4). In addition, the Ministry of Industry and Trade (MoIT) has provided a detailed plan for the CРTPP's implementation, including the main targets and tasks assigned to each agency within the MoIT. The MoIT also explains the CPTPP in various media channels to ensure that businesses understand the multilateral trade agreement. Furthermore, the MoIT coordinates and participates in the activities of the CPTPP Commission and its subcommittees to implement the framework of the agreement.5)

As a member country, Vietnam receives certain benefits from the trade agreement, as mentioned above. Vietnam also gains other advantages and disadvantages. Among the advantages, Vietnam has the opportunity to promote and increase its exports, including agriculture and textile products, because of the tariff reductions. Furthermore, Vietnam has an opportunity to attract foreign investment. To seize that opportunity, domestic and regional investors must focus more on investing in the supported industries to meet the requirements for foreign investors. Integrating into the CPTPP also requires Vietnam to improve the rule of law state that helps to increase competitiveness and facilitate trade activities. However, compared with the other CPTPP members, Vietnam has the least competitive economy and the loosest legal system. Despite its 20 years of experience with the international economic integration process, Vietnam lacks experience in a highly competitive and demanding integration environment. It only has experience with first-generation FTAs, in which open commitments and reform pressures are readily accepted for a transitional and distinctive economy (Bui, 2018). Moreover, as mentioned above, the tariff reductions that are required to become a CPTPP member provide advantages and disadvantages. Some Vietnamese industries that are not well-protected by high tariffs face aggression from international competitors with vast experience and financial resources. Certain industries, such as the automobile and agriculture industries, will face intense competition from CPTPP member countries. Vietnam also faces three major challenges related to intellectual property: the lack of a regulation that criminalizes intellectual

4) http://hanoitimes.vn/vietnam-trade-minister-highlights-preliminary-successes-from-evfta-cptpp-314295.html

5) https://vietnamnews.vn/economy/506762/ministry-issues-plans-for-cptpp-implementation.html 
property violations, as the CPTPP requires; the protection of medicines, especially test databases; and issues related to agriculture (Nguyen, 2018).

Under the СРТPP, the food, beverages and tobacco, clothing and leather, leather products, chemicals, plastic products, transport equipment, and machinery industries are expected to experience export growth. Imports are expected to grow for almost all sectors. In addition, the anticipated increase in foreign direct investment is expected to lead to a further expansion of the service sectors, boosting productivity growth. Private domestic firms will gain opportunities to integrate into global value chains and promote the development of small and medium enterprises. As exports increase and industries expand, the income generated from domestic production will continue to grow, leading to an increase in overall demand. However, with strict origin conditions, domestic firms and investors will have to develop Vietnam's sourcing industries to benefit from the FTA. The major challenge facing domestic firms is their lack of preparation to leverage the СРТPP. If their industries are weak and have strict origin conditions, it will be difficult for firms to fully realize the benefits of the СРТРP.

As the CPTPP provides advantages and disadvantages to Vietnam's enterprises, its impacts will be revealed through business performance over the long term. In the short term, however, its influence may be reflected on the stock exchange around important milestones related to Vietnam's ratification of the CPTPP. Our study, which employs an event study methodology, can be considered the first stage in measuring the impacts of the CPTPP, as it evaluates the reactions of Vietnamese listed firms to the news of its signing and approval.

\section{Methodology and Data}

Following Moser and Rose (2014), our empirical analysis proceeds in two steps. First, we generate abnormal returns for Vietnam's listed firms and measure the reactions of Vietnam's stock exchanges to the CPTPP's signing using the event study methodology. In the second step, we investigate whether any abnormal returns due to the CPTPP's announcement vary across listed firms on Vietnam's stock markets.

\section{A. Event study}

The event study methodology allows us to evaluate the effects of the CPTPP on the performance of firms listed on Vietnam's stock exchanges. Prior studies apply this methodology to gauge the effect of the arrival of new information on stock prices. The main assumptions of the event study methodology are that the market processes information about an event efficiently and without bias and that information influences stocks' values across firms with similar information arrivals. 
In an event study, the event that may affect a firm's performance may be within or outside the firm's control. Vietnam's adoption of the CPTPP is considered to be an event that is outside of a firm's control. Fama et al. (1969) first used the event study methodology for stock splits. According to Campbell et al. (1997), an event study should follow five steps: determine the event and its window, establish firm selection criteria, compute normal and abnormal returns for each listed firm in the sample set, estimate model parameters using data in the estimation window, and test whether the abnormal returns are statistically different from zero.

In this study, we estimate the model using data from 139 to 20 days prior to the CPTPP's signing or implementation date. The estimation period ends 20 days before the event date, which allows us to exclude potential abnormal returns due to the event. MacKinlay (1997) suggests that 120 trading days is a standard estimation period for an event study. To translate calendar days into event days, we define the date of the CPTPP's signing or implementation as day 0 . However, we use the event window of $(-1 ;+1)$, which is also recommended by MacKinlay (1997) as the most accurate window because it allows for spillover effects in the surrounding days and does not weaken the test's power. Moreover, using a long event window can make it harder to control for confounding effects, reducing the power of statistical tests and resulting in false conclusions about the event's significance (McWilliams \& Siegel, 1997). Accordingly, a three-day window may be long enough to capture the significant effects of the event of interest.

Following Gupta and Goldar (2005), Dasgupta et al. (2006), and Cañón-de-Francia and Garcés-Ayerbe (2009), we estimate abnormal returns using market adjusted returns. Accordingly, we define the abnormal return as $A R_{i t}=R_{i t}-R_{m t}$, where $R_{i t}$ is the return of security $i$ in period $t$ and $R_{m t}$ is the return on the market portfolio at time $t$. This model supports a linear relationship between a stock's return and the market return over a given period (Sharpe, 1964). Hence, stock returns are given by:

$$
\begin{aligned}
& R_{i t}=\alpha_{i}+\beta_{i} R_{m t}+\epsilon_{i t} \\
& \text { with } E\left(\epsilon_{i t}=0 \text { and } \operatorname{Var}\left(\epsilon_{i t}\right)=\sigma_{\epsilon_{i}}^{2}\right)
\end{aligned}
$$

where $t$ is the time index; $i=1,2, \ldots, N$ represents individual securities; $R_{i t}$ and $R_{m t}$ are the returns on stock $i$ and the market portfolio $m$, respectively, during period $t ; \alpha_{i}$ is the intercept of the relationship for stock $i ; \beta_{i}$ is the slope of the relationship of stock $i$ with the market return; and $\epsilon_{i t}$ is the error term associated with stock $i$ and time $t$.

As mentioned above, Equation (1) is generally estimated over the period from 139 to 20 days prior to the CPTPP's signing or implementation date.6) The event window spans one

6) We only use the period $(-139,-20)$ to estimate two Sharpe coefficients in Equation 1. 
day prior to one day after the event. We also check that no other contaminant event occurs in the event window $(-1 ;+1)$. The estimated values $\widehat{\alpha_{i}}$ and $\widehat{\beta_{i}}$ in Equation 1 allow us to predict the normal returns during the days covered by the event window. The prediction error, or the estimated abnormal return $\widehat{A R}_{i t}$ for stock $i$ on day $t$ (i.e., the difference between the actual return and the predicted normal return) is then calculated as:

$$
\widehat{A R_{i t}}=R_{i t}-\hat{\alpha}_{i}-\hat{\beta}_{i} R_{m t}
$$

If our sample includes multiple events, we can aggregate the abnormal returns across several events. Hence, the mean abnormal return for day $t$ within the event window is given by:

$$
\widehat{M A R}_{i t}=\frac{1}{N} \sum_{i=1}^{N}{\widehat{A R_{i t}}}
$$

where $N$ is the number of announcements in the sample. However, if the event period is longer than one day, we can estimate the cumulate abnormal return $C \widehat{A R}_{i}$ over the period $\left(T_{1}-T_{2}\right)$ as follows:

$$
C \widehat{A R}_{i}\left(T_{1}, T_{2}\right)=\Sigma_{t=T_{1}}^{t=T_{2}} \widehat{A R_{i t}}
$$

Next, we test whether the abnormal returns are statistically different from zero. We first use the traditional parametric t-test developed by Brown and Warner (1985). The Brown-Warner test assumes that the mean abnormal returns are independently and identically normally distributed. Consequently, the test statistic for any given day is given as:

$$
Z=\frac{\overline{A R_{t}}}{\sigma \sqrt{N}} \sim N(0,1)
$$

where the standard deviation of the residuals for the estimation period is used to estimate $\sigma$. Given the assumption that the residuals of the abnormal performance are uncorrelated between stocks (i.e., $\operatorname{Var}\left(\epsilon_{i t}\right)=\sigma_{\epsilon_{i}}^{2}$ ), the standard deviation of abnormal performance is based on the

7) In sum, to predict the abnormal return $\widehat{A R_{i t}}$ for stock $i$ on day $t$, we must first obtain the estimated values of the coefficients $\alpha$ and $\beta$ in Equation 1. We then use the estimated coefficients, $\widehat{\alpha_{i}}$ and, $\hat{\beta_{i}}$ in Equation 2 to predict abnormal returns $\widehat{A R_{i t}}$ over the CPTPP event window. 
standard deviation of each stock performance measure for the sample firms during the estimation period. Accordingly, if $\mathrm{T}$ indicates the length of the estimation period, then the test statistic on day 0 is given as:

$$
t_{\text {stat }}=\frac{\frac{1}{N} \sum_{i=1}^{N} A R_{i 0}}{\frac{1}{N} \sqrt{\sum_{i=1}^{N} \frac{1}{T-1} \sum_{t=1}^{T}\left(A R-\sum_{i=1}^{T} \frac{A R_{i t}}{T}\right)^{2}}}
$$

with $(T-1)$ degrees of freedom and using Student's $t$ distribution. In the Brown-Warner test, calculating the standard deviation of the residuals from the estimation period makes it possible to solve a probable cross-sectional dependence problem.

The second test adopted in this study is the Boehmer-Musumeci-Poulse (BMP) test developed by Boehmer et al. (1991). The BMP test is a cross-sectional approach that relies on the use of standardized abnormal returns. The standardized abnormal return of firm $i$ on the event date $S R_{i, E}$ is given as follows:

$$
S R_{i, E}=\frac{A R_{i, E}}{\sigma_{i} \sqrt{1+\frac{1}{T}+\frac{\left(R_{m, E-} \overline{R_{m}}\right)^{2}}{\sum_{t=1}^{T}\left(R_{m, t}-\overline{R_{m}}\right)^{2}}}}
$$

The BMP test statistic is then:

$$
B M P=\frac{\frac{1}{N} \sum_{i=1}^{N} S R_{i, E}}{\sqrt{\frac{1}{N(N-1)} \sum_{i=1}^{N}\left(S R_{i, E}-\sum_{i=1}^{N} \frac{S R_{i, E}}{N}\right)^{2}}}
$$

The BMP test uses the event-induced variance. This test seems to be more robust to variations in idiosyncratic risk than the BW test is because the firm-level residual volatility is only used to standardize the abnormal returns.

Second, our nonparametric test, the Corrado rank test, does not require a symmetric crosssectional distribution of the excess returns and accounts for the magnitude of excess returns. The Corrado test uses all of the time series observations for each stock. Corrado (1989) considers a sample of $m$ abnormal returns for each of $N$ securities. In the Corrado test, the expected rank of the event day is $\frac{m+1}{2}$ under the null hypothesis. Defining the rank of the abnormal 
returns as $K_{i t}=\operatorname{rank}\left(A R_{i t}\right)$, the test statistic for the null hypothesis of no abnormal return on event day 0 is:

$$
C_{\text {rank }}=\frac{1}{N} \sum_{i=1}^{N}\left(\frac{K_{i 0}-\frac{m+1}{2}}{s(K)}\right)
$$

with a standard deviation of:

$$
s(K)=\sqrt{\frac{1}{m} \sum_{t=1}^{T}\left[\frac{1}{N} \sum_{i=1}^{N}\left(K_{i t}-\frac{m+1}{2}\right)\right]^{2}} .
$$

Under the null hypothesis of no abnormal returns, the rank of the excess returns on day 0 follows a uniform distribution. Finally, the test statistic for the null hypothesis of no cumulative abnormal returns over the period $\left(T_{1}-T_{2}\right)$ is given by the following expression:

$$
C_{\text {rank }}^{\left(T_{1}-T_{2}\right)}=\frac{\frac{1}{N}}{\sqrt{T_{2}-T_{1}+1}} \sum_{i=1}^{N} \Sigma_{t=T_{1}}^{T_{2}} \frac{\left(K_{i t}-80,5\right)}{s(K)} \quad \sim N(0,1)
$$

Boehmer et al. (1991) suggest that Corrado's rank statistics based on medians are more resistant to the event-induced variance on day 0 and perform better than the traditional BrownWarner test does. Furthermore, MacKinlay (1997) argues that the Corrado non-parametric test should be used not in isolation but rather in conjunction with parametric tests. Thus, the nonparametric test supports the robustness of the conclusions based on the parametric test.

\section{B. Firm characteristics and abnormal returns}

In the first stage of the analysis, we measure the reaction of Vietnam's stock markets to news about the СРТPP. However, we are not solely interested in the intrinsic characteristics of the abnormal returns in the Vietnamese market due to the CPTPP's announcement. In the second stage, we therefore seek to understand why the abnormal returns vary across firms by presenting a formal statistical analysis of the cross-sectional determinants of the abnormal returns associated with firm performance. We calculate abnormal returns for individual firms using the expected returns derived from the estimated market model given by Equation 1. More specifically, we calculate the abnormal return as the difference between the actual return and the return predicted by the market model. We then estimate the following equation: 


$$
A R_{i t}=\theta_{i}+\gamma F I R_{i t}+u_{i t}
$$

where $F I R_{i t}$ is a set of indicators measuring different aspects of firm performance at time $t, u_{i t}$ is the residual, $\gamma$ is a vector of the coefficients of interest, and $\theta_{i}$ is a random intercept. Based on Equation 12, our main hypothesis of interest is that the financial market performance of a listed firm depends on other aspects of its performance. Two distinct strands of the literature discuss indicators of firm performance. The first strand is based on economic tradition and emphasizes the importance of external market factors in determining a firm's success. For instance, Ravenscraft (1983) argues that a firm's market share, growth, concentration, capital intensity, and advertising intensity are significantly positively associated with its operating income. The second strand addresses the behavioral and sociological paradigm and views organizational factors and their fit with a firm's environment as the major determinants of success. Wiklund and Shepherd (2003) argue that knowledge-based resources (i.e., resources that can be applied to discovering and leveraging opportunities) are positively related to firm performance and that a firm's entrepreneurial strategic orientation can enhance this relationship. Along similar lines, Ahmada and Schroeder (2003) show that strategic human resource management has important impacts on organizational performance in particular and on firm

performance in general. Based on the existing literature, we include the follow regressors in Equation 12:

- A human resources factor, captured by the number of employees;

- Accounting performance, measured by the return on assets (ROA) and return on equity (ROE) ratios and the firm's net profit;

- Firm size, measured by the firm's total assets and total revenue;

- Market share, measured by the firm's total equity.

In short, in the second stage of the analysis, we regress the abnormal returns of all of Vietnam's listed firms on the seven firm characteristics listed above.

\section{Data setting}

As mentioned above, we empirically analyze the potential impacts of the CPTPP on the financial performance of Vietnam's listed firms, which we measure using the variation in their stock prices. Regarding news of the CPTPP, we can consider two separate events: the CPTPP's signing on November 12, 2018, and the CPTPP's implementation on January 14, 2019. However, our empirical study only considers the CPTPP's signing date, November 12, 2018, as the event date for two reasons. First, after the CPTPP was ratified, its implementation date was announced. 
This date should not be considered news for stock markets. Second, the period between the CPTPP's signing and implementation is short (i.e., only 60 days). Thus, if we consider the CPTPP's implementation date as the second event date, our estimation period around this event is contaminated by the impact of potentially related events, such as the CPTPP's signing.

Data on stock prices and firm's characteristics are provided by StoxPlus Corporation ${ }^{8)}$. To measure the market portfolio, we use the index of the stock market on which the firms under consideration are traded. The study includes $\mathbf{7 7 5}$ companies from several sectors that are traded on Vietnam's two stock exchanges, namely, the Ho Chi Minh (HOSE) and Hanoi Stock Exchanges (HNX). Vietnam's stock exchanges are represented not only by the two main stock indexes, that is, the HNX index for the HNX and the VN-Index for the HOSE but also by other stock indexes, namely, the VNX-Allshare, VNX-Allshare, VN30, and HNX30 indexes.9) The evolution of these indexes around the CPTPP event date is displayed in Figure 1.

Figure 1. Evolution of Vietnam's stock indexes

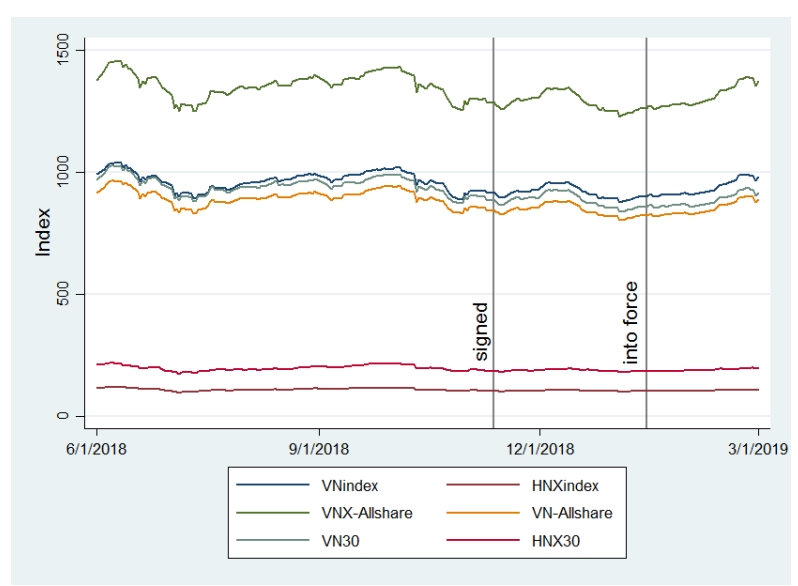

Note: The two vertical lines inside the figure indicate two milestones in the CPTPP's framework in Vietnam. The agreement was signed on November

12, 2018, and went into force on January 14, 2019.

(Source) Author's illustration

8) StoxPlus, an associate company of Nikkei Inc. and QUICK Corp., is a pioneer in providing information services to Vietnam's financial institutions. Its address is $5^{\text {th }}$ Floor, Anh Minh Building, 36 Hoang Cau, O Cho Dua, Dong Da, Hanoi, Vietnam. Tel: (84-24) 35626962.

9) VNX-Allshare is a common index of 451 stocks, of which 237 are from the HOSE and 214 are from the HNX, accounting for around $92 \%$ of the total market capitalization.

VN30 is an index of 30 traded firms on the HOSE with high market capitalization and liquidity that meet the screening criteria.

HNX30 is an index of 30 traded firms on the HNX with high market capitalization and liquidity that meet the screening criteria.

VN-Allshare is an index combining stocks from the VN100 and VNSmallcap indexes. VN100 is an index of stocks included in the VN30 and VNMidcap indexes, where the latter is an index of 70 stocks listed on the HOSE with medium capitalization levels. VNSmallcap is an index of firms with small capitalization levels that are listed on the HOSE. 
Figure 1 shows that the common index, VNX-Allshare, which represents both stock exchanges, exhibits the same pattern as the VN-Index, VN-Allshare, and VN30 exhibit. Focusing on the two important events related to Vietnam joining the CPTPP, we can see that these indexes decreased slightly after the agreement was signed but returned to an upward trend by the end of 2018. Since the agreement went into force on January 14, 2019, stock prices on the HOSE have gradually increased. However, the HNX index and HNX30 have remained stable over time. It seems that stocks on Hanoi's exchange were not influenced by the CPTPP, but we confirm this suspicion in the next sections.

Specifically, our empirical analysis is based on two subsets of data: firms listed on the HOSE and firms listed on the HNX. Moreover, for each subset, we classify Vietnam's listed firms within different sectors according to their profiles. Each firm is classified as belonging to one of the following sectors: food and live animals; beverages and tobacco; crude materials; mineral fuels, lubricants, and related materials; animal and vegetable oils, fats, and waxes; chemicals; manufactured goods; machinery and transport equipment; commercial services; and corporations, that is, groups of different businesses. In turn, commercial services include finance, banking, and insurance; construction; telecommunications; education; transportation; health services; real estate; travel; and entertainment;

Table 1. Descriptive Statistics

\begin{tabular}{ccccccc}
\hline & \multirow{2}{*}{$\begin{array}{c}\text { Number of } \\
\text { observations } \\
\text { Sample }\end{array}$} & Mean & Median & $\begin{array}{c}\text { Standard } \\
\text { deviation }\end{array}$ & Skewness & Excess kurtosis \\
\cline { 3 - 7 } & 381 & .0298 & 0 & 3.5007 & .2319 & 8.9354 \\
HOSE & 394 & -.0037 & 0 & 2.7281 & .0613 & 4.2018 \\
HNX & 288 & .0033 & .1159 & 1.3408 & -.6279 & 4.5779 \\
VNindex & 288 & -.0251 & .0465 & 1.4584 & -.5183 & 5.7213 \\
HNXindex & 288 & -.0036 & .1157 & 1.2866 & -.6215 & 4.6902 \\
VNX-Allshare & 288 & -.0121 & .1193 & 1.2759 & -.6372 & 4.6500 \\
VN-Allshare & 288 & -.0186 & .0977 & 1.3933 & -.5197 & 4.4085 \\
VN30 & 288 & -.0137 & .1669 & 1.7620 & -.4119 & 5.6235 \\
HNX30 & & & & &
\end{tabular}

(Source) Authors' creation

Table 1 reports descriptive statistics of the stock returns of firms listed on the two markets and the returns of common indexes. The descriptive statistics of stock returns are averages of statistics calculated at the individual security level. Table 2 reports the correlations between stock returns, market returns, and a set of control variables. Most of the correlation coefficients are significant, which aids in modeling and helps to confirm our choice of variables. 
Table 2. Correlation Coefficient Matrix

\begin{tabular}{ccc}
\hline \multirow{2}{*}{ Independent variable } & \multicolumn{2}{c}{ Dependent variable : Stock return } \\
\cline { 2 - 3 } & VNindex sample & HNX sample \\
\hline Market return & $0.2152^{*}$ & $0.0860^{*}$ \\
ROA & 0.0044 & 0.0042 \\
ROE & $0.0064^{*}$ & 0.0019 \\
Total Sales & 0.0006 & 0.0001 \\
Net profit & $0.0083^{*}$ & 0.0004 \\
Equity & 0.0025 & -0.0015 \\
Human Resources & 0.0059 & 0.0023 \\
\hline
\end{tabular}

(Source) Authors' creation

\section{Empirical Results}

\section{A. Abnormal stock returns around the CPTPP's signing}

Table 3 presents the market's reaction during the event window around the announcement of the CPTPP's signing. This period includes the day preceding the announcement (day -1 ), the day of the announcement (day 0 ), and the day following the announcement (day +1$)$. To reinforce our empirical findings, we also report the results of an event study using the event window $[-5 ;+5]$. The second column of Table 3 reports the number of stock prices under consideration. The third column shows the estimated cumulative average abnormal returns (CAARs) derived from adopting the CPTPP for each event window. The results of the BrownWarner, BMP, and Corrado rank tests are presented in the fourth, fifth, and sixth columns, respectively.

We find that the CAARs are all positive for each event window for the sample of all listed firms on the HOSE and HNX. The Brown-Warner and the BMP tests indicate that the empirical

Table 3. Full Sample's Event Study Results

\begin{tabular}{|c|c|c|c|c|c|c|c|c|c|c|c|c|c|c|c|}
\hline \multirow{7}{*}{ 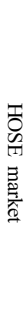 } & $\begin{array}{c}\text { Event } \\
\text { window }\end{array}$ & $\begin{array}{l}\text { Number } \\
\text { of firms }\end{array}$ & CAAR & $\begin{array}{c}\text { Brown- } \\
\text { Warner } \\
\text { test }\end{array}$ & $\begin{array}{c}\text { BMP } \\
\text { test }\end{array}$ & $\begin{array}{c}\text { Corrado } \\
\text { rank } \\
\text { test }\end{array}$ & $\begin{array}{c}\text { Skew } \\
\text { test }\end{array}$ & \multirow{7}{*}{ 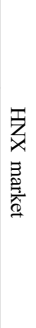 } & $\begin{array}{c}\text { Event } \\
\text { window }\end{array}$ & $\begin{array}{l}\text { Number } \\
\text { of firms }\end{array}$ & CAAR & $\begin{array}{c}\text { Brown- } \\
\text { Warner } \\
\text { test }\end{array}$ & $\begin{array}{c}\text { BMP } \\
\text { test }\end{array}$ & $\begin{array}{c}\text { Corrado } \\
\text { rank } \\
\text { test }\end{array}$ & $\begin{array}{c}\text { Skew } \\
\text { test }\end{array}$ \\
\hline & {$[-1 ; 1]$} & 195 & 0.623 & $12.063^{* * *}$ & $5.895^{* * *}$ & -0.404 & 0.053 & & {$[-1 ; 1]$} & 235 & 0.741 & $15.155^{* * *}$ & $8.603^{* * *}$ & $2.508^{* *}$ & -0.818 \\
\hline & {$[0 ; 1]$} & 199 & 0.482 & $11.429^{* * *}$ & $5.590^{* * *}$ & 0.272 & -0.205 & & {$[0 ; 1]$} & 233 & 0.533 & $13.339^{* * *}$ & $7.402 * * *$ & $1.751^{*}$ & -1.506 \\
\hline & {$[-1 ; 0]$} & 207 & 0.462 & $10.958^{* * *}$ & $5.438^{* * *}$ & 0.493 & -0.158 & & {$[-1 ; 0]$} & 245 & 0.515 & $12.911^{* * *}$ & $7.434^{* * *}$ & $2.304^{* *}$ & $-1.666^{*}$ \\
\hline & {$[-5 ; 5]$} & 195 & 1.895 & $19.172^{* * *}$ & $9.068^{* * *}$ & $-2.404^{* *}$ & $-1.704^{*}$ & & {$[-5 ; 5]$} & 232 & 2.416 & $25.804 * * *$ & $12.937 * * *$ & $1.872 *$ & $1.727^{*}$ \\
\hline & {$[0 ; 5]$} & 198 & 1.034 & $14.174 * * *$ & $7.385^{* * *}$ & $-2.048^{* *}$ & $-2.113^{* *}$ & & {$[0 ; 5]$} & 231 & 1.412 & $20.418^{* * *}$ & $11.144^{* * *}$ & $2.266^{* *}$ & $-4.458^{* * *}$ \\
\hline & {$[-5 ; 0]$} & 207 & 1.037 & $14.202^{* * *}$ & $7.361^{* * *}$ & $-2.539^{* *}$ & $-2.281^{* *}$ & & {$[-5 ; 0]$} & 245 & 1.409 & $20.377^{* * *}$ & $11.162^{* * *}$ & $2.577^{* *}$ & $-2.348 * *$ \\
\hline
\end{tabular}


results are statistically significant at the $1 \%$ level. However the Corrado rank test's results are more complex. In the case of the HOSE, we obtain statistically significant results for the event windows $[-5 ; 0],[0 ;+5]$, and $[-5 ;+5]$. These results lead us to reject the null hypothesis that no abnormal returns result from the announcement of the CPTPP's signing in the HOSE market over the estimation period $[-5 ;+5]$. In contrast, in the HNX market, our empirical results are statistically significant for the event windows $[-1 ; 0],[0 ;+1]$, and $[-1 ;+1]$. This result means that the CPTPP's signing seems to have had immediate positive impacts on the returns of firms listed on the HNX.

Although the CPTPP significantly impacts stock returns in Vietnam, the impact seems rather small in magnitude because the CAAR values range from $0.462 \%$ to $2.416 \%$. In other words, Vietnam's stock market reacted only marginally positively to the CPTPP's adoption. One possible explanation for the lack of a strong market reaction to the announcement of the CPTPP's signing may be heterogeneity within the sample in terms of firm size, firm reputation, and initial firm performance. For instance, several event studies confirm that firm size has significant impacts (e.g., Hendricks \& Singhal, 2003; Klassen \& McLaughlin, 1996). Conversely, stock price reactions may differ across industries. Thus, Table 4 shows the results of performing the event study analysis separately by industry. We also divide the full sample into two subsamples of firms with and without exporting activity.

As Table 4 shows, our empirical results vary across industries in both magnitude and significance. First, we observe that the CAARs shift from negative to positive. In addition, we do not observe abnormal returns in some cases (e.g., firms in the animal and vegetable oils sector and the machinery and transport sector listed on the HNX over the event window $[-1 ;+1])$. Second, the results of the Brown-Warner and BMP tests also differ across industries. These two tests almost support the significance of the estimated CAAR values for industries with many listed firms, namely, the services, corporations, and manufactured goods sectors. Similarly, when we classify Vietnam's listed firms according to whether their sectors have exporting activity, the two parametric tests support the statistical significance of our empirical results. Third, unlike the full-sample estimation results reported in Table 3, the non-parametric Corrado test indicates that the empirical results are not statistically significant except in some special cases. Consequently, the contrasting results of the parametric and non-parametric tests do not allow us to reject the null hypothesis of no abnormal returns at the industry level.

We also present graphical evidence using the event study methodology. Figures 2 and 3 plot the CAARs around the CPTPP's signing for the HNX and HOSE markets, respectively. The shaded area shows the baseline event window from $t-5$ to $t+5$. 


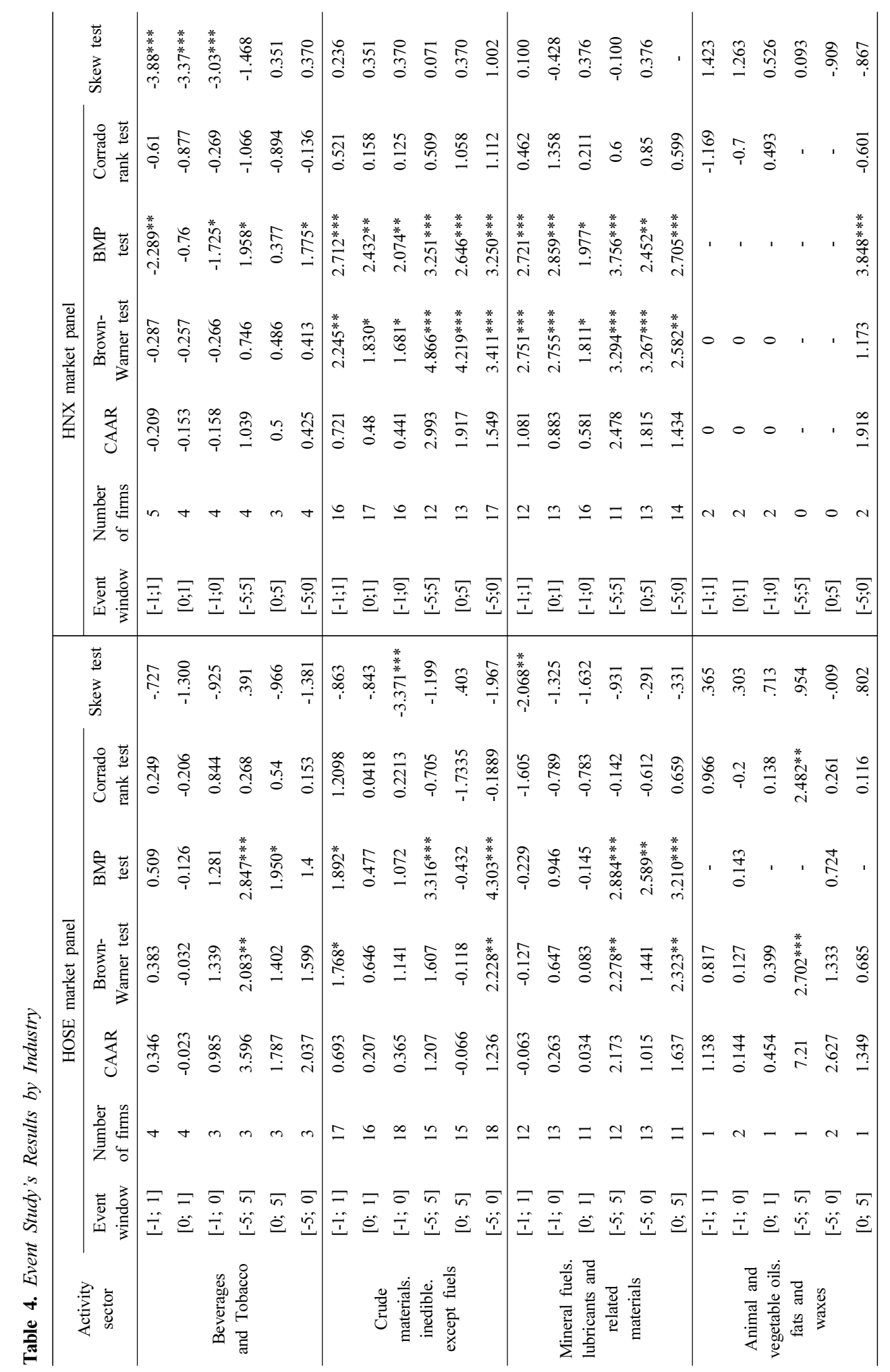




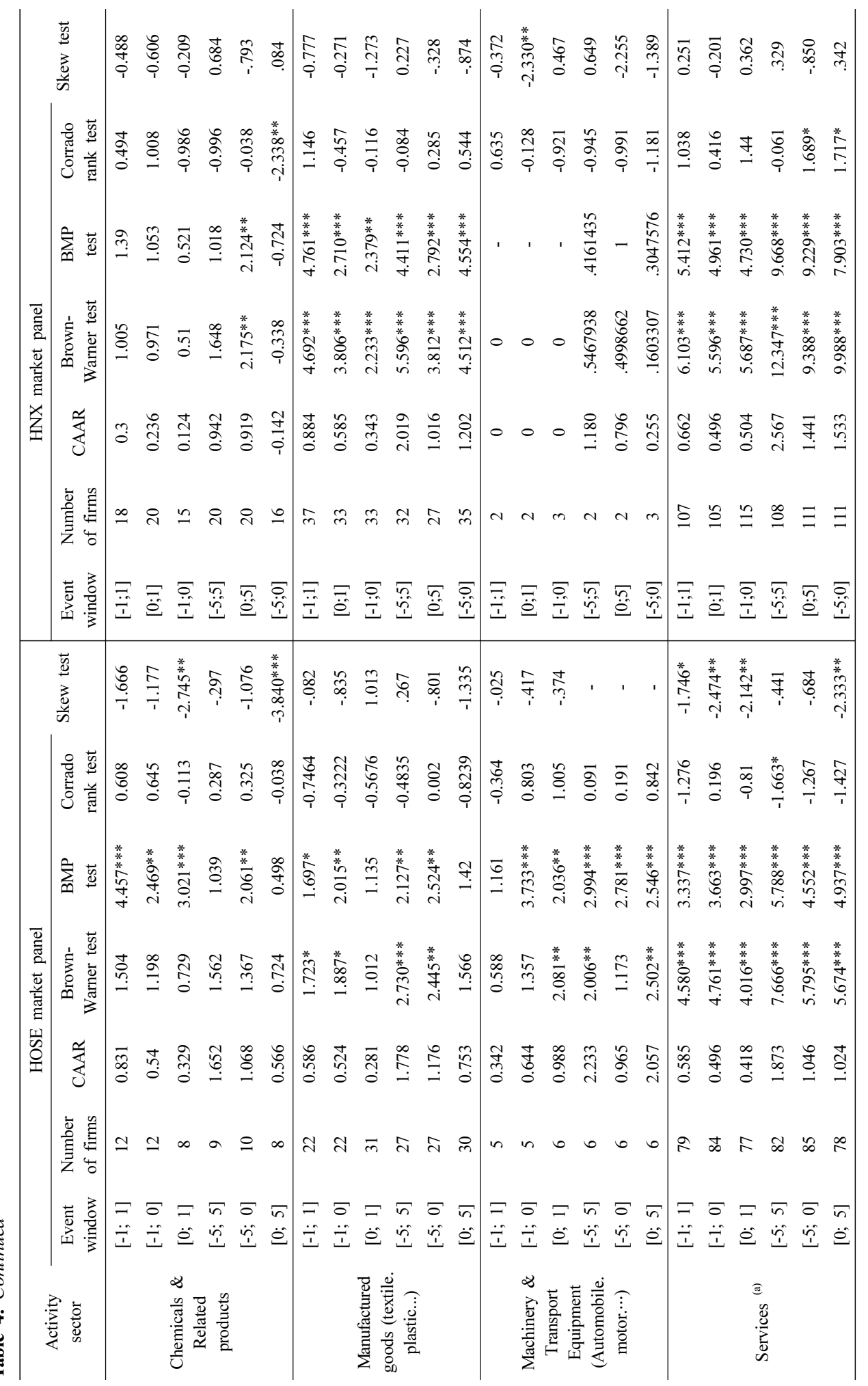




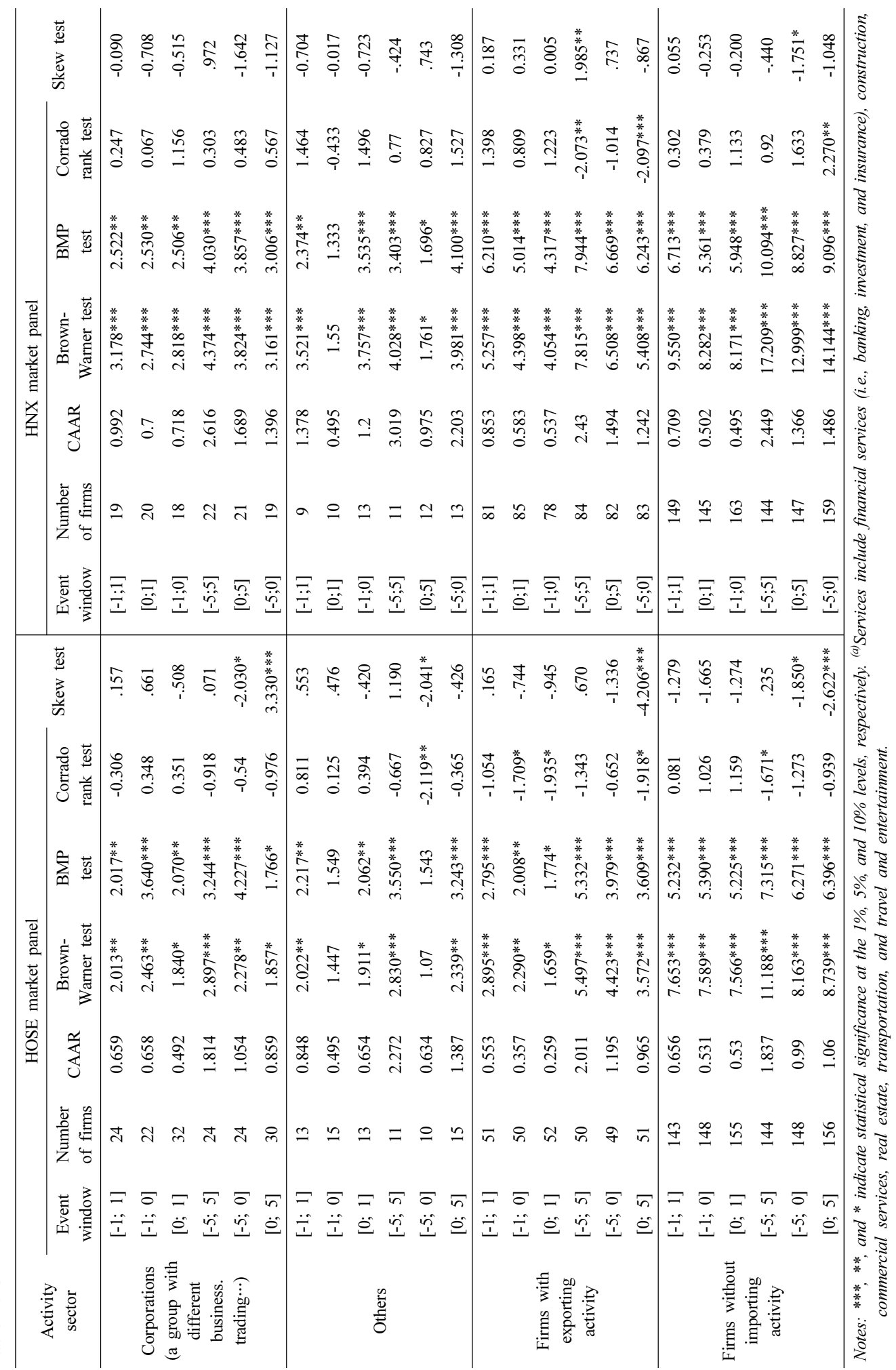


Figure 2. CAAR around CPTPP event - HNX market

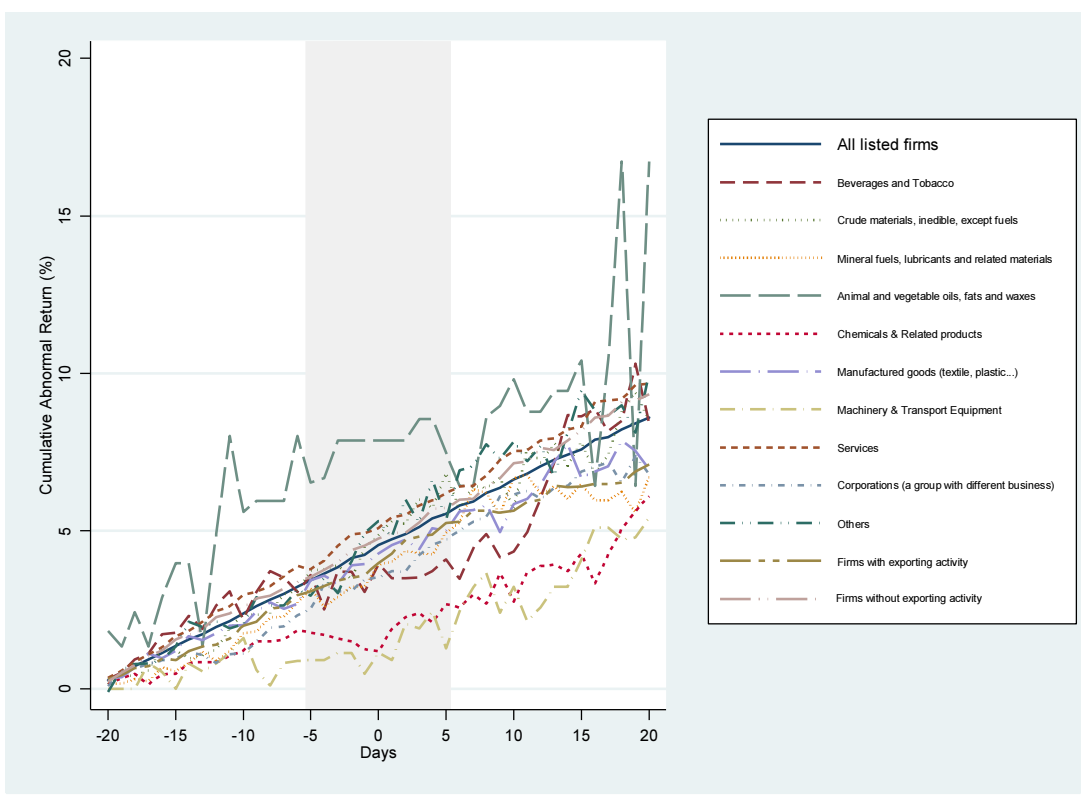

(Source) Authors' illustration

Figure 3. CAAR around CPTPP event - HOSE market

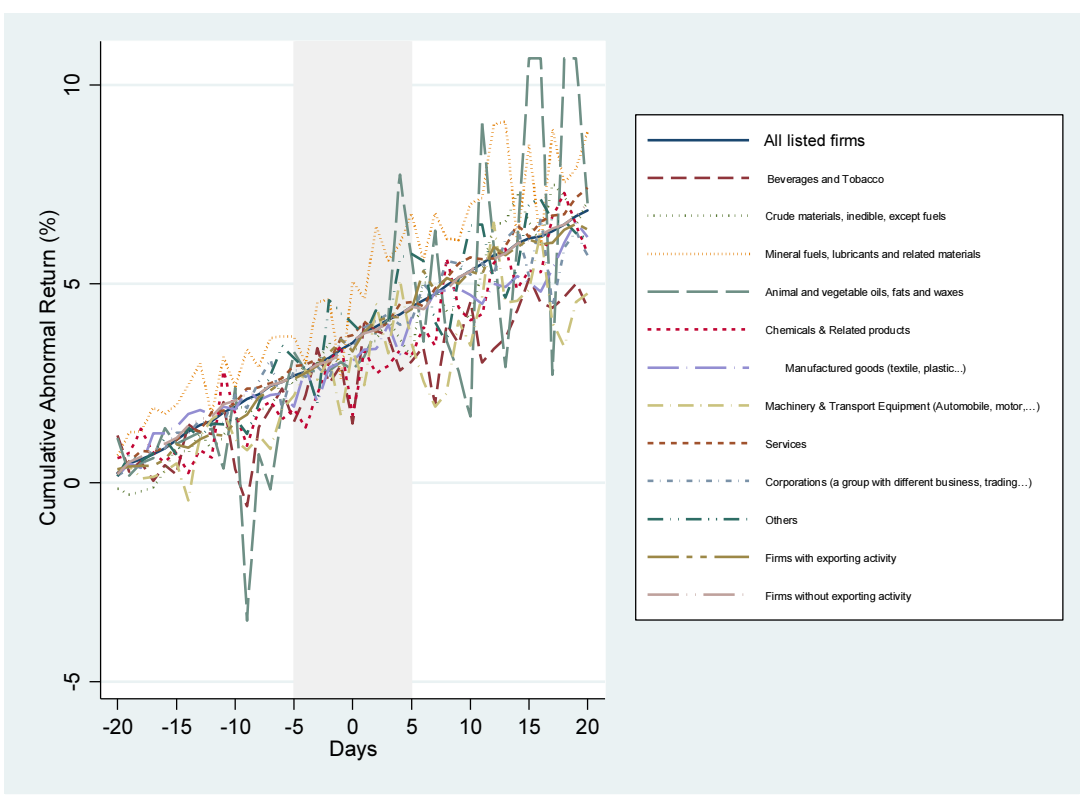

(Source) Authors' illustration 
As Figure 2 shows, on the HNX market, the CAARs are different from zero and almost positive before the CPTPP signing. Moreover, the trends in the CAARs before and after the signing appear not to be significantly different. For instance, the CAARs of all listed firms are constantly increasing, and the news of the CPTPP's signing matters only in that it slightly influences the HNX stock market. Compared with the HNX market, the HOSE market has a more complex reaction to the CPTPP's signing. As Figure 3 shows, the CAARs after the signing seem to be more volatile than those before the event are.

Overall, we offer insights into the reaction of Vietnam's stock markets to the announcement of the CPTPP's signing by analyzing Vietnam's abnormal stock returns. We reveal that the news only slightly effects Vietnam's stock exchanges, and this impact seem to be hidden in the sector-level analyses.

\section{B. Determinants of abnormal returns}

Our first event study results lead to questions on the variation in Vietnam's abnormal stock returns. Thus, in the second stage of our analysis, we aim to understand whether other factors besides the news about the СРТPP affect listed firms' abnormal returns. To this end, we conduct a formal statistical analysis of the cross-sectional determinants of the abnormal returns associated with different firm characteristics. Specifically, we estimate Equation 12, in which individual heterogeneity is random, using the generalized least squares (GLS) model. To check for sensitivity, we consider two event windows: $[-1 ;+1]$ and $[-5 ;+5]$. We also estimate Equation 12 for the full sample including all listed firms, a sample including only firms with exporting activity, and a sample including only firms without exporting activity. We report the results of estimating the GLS model in Table 5.

Several important findings can be drawn from our analysis. We show that the impacts of a firm's characteristics on its abnormal returns vary across different event windows. For instance, a firm's revenue significantly negatively impacts the abnormal returns in the event window $[-1 ;+1]$, but this impact becomes statistically insignificant over time. We also find that the impacts of firm's characteristics on abnormal returns vary across stock markets and firms' integration characteristics. First, compared with the reaction of returns in the HOSE market, the HNX market's returns react more sensibly given the listed firms' characteristics. Over the event window $[-1 ;+1]$, the HNX market's returns depend positively on firms' total equity and ROE ratios but depend negatively on firms' total revenues and total net benefits. These impacts change when we use the event window $[-5 ;+5]$ instead of $[-1 ;+1]$. For instance, in the longer window, the significant positive impacts of equity and the ROE on returns are lower, and the negative impacts of revenues and net profits become statistically insignificant. In the same event windows, the human resources indicator, measured by number of employees, plays little role in explaining abnormal HOSE returns around the CPTPP's approval, which is not the case for other firm characteristics. Second, 
the impacts of firms' characteristics on abnormal stock returns change depending on firms' integration levels. For instance, in the shorter event window $[-1 ;+1]$, the returns of HNX firms without exporting activity respond to the change in the market environment as a function of several firm characteristics, such as equity, revenue, the ROA, the ROE, and net profit. By contrast, in the larger event window $[-5 ;+5]$, firms' revenues, human resources, ROAs, and net benefits significantly impact returns for firms with exporting activity listed on the HOSE. However, none of firm characteristics explains the abnormal stock returns of HOSE firms with no exporting activity.

Table 5. GLS Estimation's Results

\begin{tabular}{|c|c|c|c|c|c|c|c|c|c|c|c|c|}
\hline \multirow{3}{*}{$\begin{array}{l}\text { Independent } \\
\text { variables }\end{array}$} & \multicolumn{4}{|c|}{ Full sample } & \multicolumn{4}{|c|}{ Firms with exporting activity sample } & \multicolumn{4}{|c|}{ Firms without exporting activity sample } \\
\hline & \multicolumn{2}{|c|}{ HNX Market } & \multicolumn{2}{|c|}{ HOSE Market } & \multicolumn{2}{|c|}{ HNX Market } & \multicolumn{2}{|c|}{ HOSE Market } & \multicolumn{2}{|c|}{ HNX Market } & \multicolumn{2}{|c|}{ HOSE Market } \\
\hline & {$[-1 ;+1]$} & {$[-5 ;+5]$} & {$[-1 ;+1]$} & {$[-5 ;+5]$} & {$[-1 ;+1]$} & {$[-5 ;+5]$} & {$[-1 ;+1]$} & {$[-5 ;+5]$} & {$[-1 ;+1]$} & {$[-5 ;+5]$} & {$[-1 ;+1]$} & {$[-5 ;+5]$} \\
\hline $\begin{array}{l}\text { Human } \\
\text { resource }\end{array}$ & $\begin{array}{c}0.074 \\
(0.107)\end{array}$ & $\begin{array}{c}0.019 \\
(0.057)\end{array}$ & $\begin{array}{l}0.167^{* *} \\
(0.077)\end{array}$ & $\begin{array}{c}0.013 \\
(0.045)\end{array}$ & $\begin{array}{l}0.328^{*} \\
(0.17)\end{array}$ & $\begin{array}{l}0.004 \\
(0.09)\end{array}$ & $\begin{array}{c}0.436^{* *} \\
(0.174)\end{array}$ & $\begin{array}{c}0.224 * * * \\
(0.08)\end{array}$ & $\begin{array}{l}-0.074 \\
(0.15)\end{array}$ & $\begin{array}{c}0.016 \\
(0.080)\end{array}$ & $\begin{array}{l}0.016 \\
(0.09)\end{array}$ & $\begin{array}{c}0.013 \\
(0.045)\end{array}$ \\
\hline Asset & $\begin{array}{l}-1.160 \\
(0.957)\end{array}$ & $\begin{array}{l}-0.705 \\
(0.511)\end{array}$ & $\begin{array}{l}-0.255 \\
(0.876)\end{array}$ & $\begin{array}{c}0.200 \\
(0.511)\end{array}$ & $\begin{array}{c}0.36 \\
(1.61)\end{array}$ & $\begin{array}{l}-0.664 \\
(0.85)\end{array}$ & $\begin{array}{l}-2.103 \\
(1.814)\end{array}$ & $\begin{array}{l}-1.28 \\
(0.82)\end{array}$ & $\begin{array}{c}-1.896 \\
(1.25)\end{array}$ & $\begin{array}{l}-0.646 \\
(0.668)\end{array}$ & $\begin{array}{c}0.62 \\
(0.99)\end{array}$ & $\begin{array}{c}0.200 \\
(0.511)\end{array}$ \\
\hline Equity & $\begin{array}{c}2.207^{* *} \\
(1.114)\end{array}$ & $\begin{array}{l}1.056^{*} \\
(0.594)\end{array}$ & $\begin{array}{c}0.297 \\
(0.865)\end{array}$ & $\begin{array}{l}-0.576 \\
(0.550)\end{array}$ & $\begin{array}{l}-0.707 \\
(1.95)\end{array}$ & $\begin{array}{c}1.13 \\
(1.02)\end{array}$ & $\begin{array}{c}0.898 \\
(1.607)\end{array}$ & $\begin{array}{l}0.312 \\
(0.73)\end{array}$ & $\begin{array}{c}3.234^{* *} \\
(1.47)\end{array}$ & $\begin{array}{c}0.873 \\
(0.788)\end{array}$ & $\begin{array}{c}-0.598 \\
(1.06)\end{array}$ & $\begin{array}{l}-0.576 \\
(0.550)\end{array}$ \\
\hline Revenue & $\begin{array}{l}-1.26^{*} \\
(0.737)\end{array}$ & $\begin{array}{l}-0.379 \\
(0.393)\end{array}$ & $\begin{array}{l}-0.239 \\
(0.398)\end{array}$ & $\begin{array}{c}0.331 \\
(0.257)\end{array}$ & $\begin{array}{c}-0.083 \\
(1.6)\end{array}$ & $\begin{array}{l}-0.464 \\
(0.85)\end{array}$ & $\begin{array}{c}0.755 \\
(0.766)\end{array}$ & $\begin{array}{l}0.647^{*} \\
(0.35)\end{array}$ & $\begin{array}{c}-1.470^{*} \\
(0.89)\end{array}$ & $\begin{array}{l}-0.282 \\
(0.477)\end{array}$ & $\begin{array}{c}-0.078 \\
(0.5)\end{array}$ & $\begin{array}{c}0.331 \\
(0.257)\end{array}$ \\
\hline ROA & $\begin{array}{l}-1.202 \\
(0.987)\end{array}$ & $\begin{array}{l}-0.658 \\
(0.526)\end{array}$ & $\begin{array}{l}-0.650 \\
(0.871)\end{array}$ & $\begin{array}{c}0.024 \\
(0.514)\end{array}$ & $\begin{array}{l}0.654 \\
(1.67)\end{array}$ & $\begin{array}{l}-0.326 \\
(0.88)\end{array}$ & $\begin{array}{l}-2.714 \\
(1.733)\end{array}$ & $\begin{array}{c}-1.387^{*} \\
(0.79)\end{array}$ & $\begin{array}{c}-2.214^{*} \\
(1.28)\end{array}$ & $\begin{array}{l}-0.762 \\
(0.687)\end{array}$ & $\begin{array}{l}0.615 \\
(0.99)\end{array}$ & $\begin{array}{c}0.024 \\
(0.514)\end{array}$ \\
\hline ROE & $\begin{array}{c}2.344 * * \\
(1.112)\end{array}$ & $\begin{array}{l}1.001^{*} \\
(0.593)\end{array}$ & $\begin{array}{c}0.832 \\
(0.845)\end{array}$ & $\begin{array}{l}-0.413 \\
(0.538)\end{array}$ & $\begin{array}{l}-0.891 \\
(1.92)\end{array}$ & $\begin{array}{l}0.828 \\
(1.02)\end{array}$ & $\begin{array}{c}2.051 \\
(1.563)\end{array}$ & $\begin{array}{l}0.793 \\
(0.71)\end{array}$ & $\begin{array}{c}3.658^{* *} \\
(1.47)\end{array}$ & $\begin{array}{c}0.949 \\
(0.787)\end{array}$ & $\begin{array}{l}-0.498 \\
(1.04)\end{array}$ & $\begin{array}{l}-0.413 \\
(0.538)\end{array}$ \\
\hline Net profit & $\begin{array}{l}-1.255^{*} \\
(0.735)\end{array}$ & $\begin{array}{l}-0.398 \\
(0.392)\end{array}$ & $\begin{array}{l}-0.190 \\
(0.396)\end{array}$ & $\begin{array}{c}0.390 \\
(0.253)\end{array}$ & $\begin{array}{c}0.17 \\
(1.63)\end{array}$ & $\begin{array}{l}-0.557 \\
(0.86)\end{array}$ & $\begin{array}{c}0.601 \\
(0.745)\end{array}$ & $\begin{array}{l}0.564^{*} \\
(0.34)\end{array}$ & $\begin{array}{c}-1.552^{*} \\
(0.89)\end{array}$ & $\begin{array}{l}-0.255 \\
(0.475)\end{array}$ & $\begin{array}{c}-0.098 \\
(0.49)\end{array}$ & $\begin{array}{c}0.390 \\
(0.253)\end{array}$ \\
\hline Constant & $\begin{array}{l}4.642^{*} \\
(2.708)\end{array}$ & $\begin{array}{c}0.507 \\
(1.445)\end{array}$ & $\begin{array}{l}4.017^{*} \\
(2.317)\end{array}$ & $\begin{array}{c}0.997 \\
(1.260)\end{array}$ & $\begin{array}{l}9.566^{*} \\
(4.66)\end{array}$ & $\begin{array}{l}0.153 \\
(2.46)\end{array}$ & $\begin{array}{c}8.763 \\
(5.624)\end{array}$ & $\begin{array}{c}7.229^{* * *} \\
(2.55)\end{array}$ & $\begin{array}{l}3.067 \\
(3.5)\end{array}$ & $\begin{array}{c}0.988 \\
(1.878)\end{array}$ & $\begin{array}{l}1.396 \\
(2.43)\end{array}$ & $\begin{array}{c}0.997 \\
(1.260)\end{array}$ \\
\hline R-squared & 0.043 & 0.020 & 0.048 & 0.058 & 0.082 & 0.046 & 0.206 & 0.254 & 0.069 & 0.029 & 0.01 & 0.029 \\
\hline $\begin{array}{l}\text { Number of } \\
\text { observation }\end{array}$ & 396 & 3932 & 1009 & 3701 & 348 & 1276 & 273 & 1001 & 570 & 2090 & 244 & 2678 \\
\hline
\end{tabular}

In sum, both the stock market's reaction to the news of the CPTPP's signing and the impacts of listed firms' characteristics on returns vary across the HNX and the HOSE. This result can be mainly explained by differences in the characteristics of firms listed on the HNX and the HOSE. For instance, to list on the HOSE, a company must conduct profitable business operations for the two consecutive years immediately preceding the year of registration.

However, to list on the HNX, a company only needs to have profitable business operations for the year immediately preceding the year of registration. Together with higher profits, the HOSE firms face more stringent capital requirements than the HNX firms do. Moreover, the information transparency indicator of HOSE firms is much greater than that of HNX firms. Because of its greater transparency and market size, the HOSE market has more advantages in attracting foreign investors than the HNX market has. 


\section{Sensitivity of the empirical analysis}

This subsection describes robustness checks to examine the results' sensitivity to alternative estimation strategies. First, one econometric issue in event studies is having a non-random sample, which can lead to non-normal distributions and, thus, incorrect inferences based on incorrect standard error calculations. In addition, because Vietnam's stock markets are small, our work is based only on samples that include at most 207 traded firms. Non-normality and a limited number of observations can cause serious problems for testing. Thus, to ensure that our findings are robust, we implement the bootstrapped and skew-adjusted t-test developed by Johnson (1978) for the null hypothesis of no abnormal returns. The results of this test are reported in the last columns of Tables 3-4. The value of the bootstrapped skew-adjusted $t$-statistic confirms the robustness of our CAAR results.

Second, we check our results concerning the determinants of abnormal market returns using a mixed-effects model, which consists of both random and fixed effects, to estimate Equation 12. As Table 6 shows, only the empirical results for the abnormal returns of HOSE firms with exporting activity are moderately sensible when we slightly adjust our econometric methodology. Specifically, some determinants of abnormal returns in the longer event window $[-5 ; 5]$, that is, the ROA, the ROE, and net profits, also become statistically significant in the shorter event window $[-1 ; 1]$. Overall, we conclude that our key results for the determinants of abnormal market returns are reassuringly robust to different econometric tests.

Table 6. Mixed - Effect Estimation's Results

\begin{tabular}{|c|c|c|c|c|c|c|c|c|c|c|c|c|}
\hline \multirow{3}{*}{$\begin{array}{l}\text { Independent } \\
\text { variables }\end{array}$} & \multicolumn{4}{|c|}{ Full sample } & \multicolumn{4}{|c|}{ Firms with exporting activity sample } & \multicolumn{4}{|c|}{ Firms without exporting activity sample } \\
\hline & \multicolumn{2}{|c|}{ HNX Market } & \multicolumn{2}{|c|}{ HOSE Market } & \multicolumn{2}{|c|}{ HNX Market } & \multicolumn{2}{|c|}{ HOSE Market } & \multicolumn{2}{|c|}{ HNX Market } & \multicolumn{2}{|c|}{ HOSE Market } \\
\hline & {$[-1 ;+1]$} & {$[-5 ;+5]$} & {$[-1 ;+1]$} & {$[-5 ;+5]$} & {$[-1 ;+1]$} & {$[-5 ;+5]$} & {$[-1 ;+1]$} & {$[-5 ;+5]$} & {$[-1 ;+1]$} & {$[-5 ;+5]$} & {$[-1 ;+1]$} & {$[-5 ;+5]$} \\
\hline $\begin{array}{l}\text { Human } \\
\text { resource }\end{array}$ & $\begin{array}{l}0.074 \\
(0.11)\end{array}$ & $\begin{array}{c}0.019 \\
(0.057)\end{array}$ & $\begin{array}{c}0.167^{* *} \\
(0.07)\end{array}$ & $\begin{array}{c}0.078^{* *} \\
(0.04)\end{array}$ & $\begin{array}{l}0.328^{*} \\
(0.17)\end{array}$ & $\begin{array}{c}0.005 \\
(0.091)\end{array}$ & $\begin{array}{c}0.436^{* * *} \\
(0.148)\end{array}$ & $\begin{array}{c}0.224 * * * \\
(0.08)\end{array}$ & $\begin{array}{l}-0.074 \\
(0.15)\end{array}$ & $\begin{array}{l}0.004 \\
(0.09)\end{array}$ & $\begin{array}{l}0.016 \\
(0.09)\end{array}$ & $\begin{array}{l}0.013 \\
(0.05)\end{array}$ \\
\hline Asset & $\begin{array}{l}-1.159 \\
(0.95)\end{array}$ & $\begin{array}{l}-0.705 \\
(0.51)\end{array}$ & $\begin{array}{l}-0.271 \\
(0.82)\end{array}$ & $\begin{array}{l}-0.234 \\
(0.43)\end{array}$ & $\begin{array}{l}0.360 \\
(1.59)\end{array}$ & $\begin{array}{l}-0.664 \\
(0.847)\end{array}$ & $\begin{array}{l}-2.103 \\
(1.54)\end{array}$ & $\begin{array}{l}-1.28 \\
(0.82)\end{array}$ & $\begin{array}{l}-1.896 \\
(1.24)\end{array}$ & $\begin{array}{l}-0.664 \\
(0.85)\end{array}$ & $\begin{array}{l}0.621 \\
(0.98)\end{array}$ & $\begin{array}{c}0.2001 \\
(0.51)\end{array}$ \\
\hline Equity & $\begin{array}{c}2.207^{* *} \\
(1.11)\end{array}$ & $\begin{array}{l}1.056^{*} \\
(0.593)\end{array}$ & $\begin{array}{l}0.309 \\
(0.81)\end{array}$ & $\begin{array}{l}-0.117 \\
(0.42)\end{array}$ & $\begin{array}{l}-0.707 \\
(1.92)\end{array}$ & $\begin{array}{l}1.130 \\
(1.022)\end{array}$ & $\begin{array}{l}0.898 \\
1.364)\end{array}$ & $\begin{array}{l}0.312 \\
(0.73)\end{array}$ & $\begin{array}{c}3.234^{* *} \\
(1.46)\end{array}$ & $\begin{array}{c}1.13 \\
(1.02)\end{array}$ & $\begin{array}{l}-0.598 \\
(1.06)\end{array}$ & $\begin{array}{l}-0.576 \\
(0.55)\end{array}$ \\
\hline Revenue & $\begin{array}{c}-1.260^{*} \\
(0.73)\end{array}$ & $\begin{array}{l}-0.379 \\
(0.393)\end{array}$ & $\begin{array}{c}-0.236 \\
(0.38)\end{array}$ & $\begin{array}{l}0.232 \\
(0.19)\end{array}$ & $\begin{array}{l}-0.083 \\
(1.58)\end{array}$ & $\begin{array}{l}-0.464 \\
(0.843)\end{array}$ & $\begin{array}{l}0.755 \\
(0.65)\end{array}$ & $\begin{array}{l}0.647^{*} \\
(0.35)\end{array}$ & $\begin{array}{c}-1.470^{*} \\
(0.88)\end{array}$ & $\begin{array}{c}-0.464 \\
(0.84)\end{array}$ & $\begin{array}{l}-0.078 \\
(0.49)\end{array}$ & $\begin{array}{l}0.331 \\
(0.26)\end{array}$ \\
\hline ROA & $\begin{array}{l}-1.202 \\
(0.98)\end{array}$ & $\begin{array}{l}-0.658 \\
(0.526)\end{array}$ & $\begin{array}{l}-0.661 \\
(0.82)\end{array}$ & $\begin{array}{l}-0.493 \\
(0.42)\end{array}$ & $\begin{array}{l}0.654 \\
(1.65)\end{array}$ & $\begin{array}{l}-0.326 \\
(0.878)\end{array}$ & $\begin{array}{l}-2.714^{*} \\
(1.471)\end{array}$ & $\begin{array}{c}-1.387^{*} \\
(0.78)\end{array}$ & $\begin{array}{c}-2.214^{*} \\
(1.27)\end{array}$ & $\begin{array}{l}-0.326 \\
(0.88)\end{array}$ & $\begin{array}{l}0.615 \\
(0.99)\end{array}$ & $\begin{array}{l}0.024 \\
(0.51)\end{array}$ \\
\hline ROE & $\begin{array}{c}2.344^{* *} \\
(1.11)\end{array}$ & $\begin{array}{l}1.000^{*} \\
(0.593)\end{array}$ & $\begin{array}{l}0.838 \\
(0.8)\end{array}$ & $\begin{array}{l}0.182 \\
(0.41)\end{array}$ & $\begin{array}{c}-0.891 \\
(1.9)\end{array}$ & $\begin{array}{c}0.829 \\
(1.011)\end{array}$ & $\begin{array}{l}2.051^{*} \\
(1.326)\end{array}$ & $\begin{array}{l}0.793 \\
(0.71)\end{array}$ & $\begin{array}{c}3.658^{* *} \\
(1.46)\end{array}$ & $\begin{array}{l}0.828 \\
(1.01)\end{array}$ & $\begin{array}{l}-0.498 \\
(1.03)\end{array}$ & $\begin{array}{l}-0.413 \\
(0.54)\end{array}$ \\
\hline Net profit & $\begin{array}{c}-1.255^{*} \\
(0.73)\end{array}$ & $\begin{array}{l}-0.398 \\
(0.392)\end{array}$ & $\begin{array}{l}-0.187 \\
(0.37)\end{array}$ & $\begin{array}{l}0.298 \\
(0.19)\end{array}$ & $\begin{array}{c}0.17 \\
(1.61)\end{array}$ & $\begin{array}{l}-0.557 \\
(0.856)\end{array}$ & $\begin{array}{l}0.601^{*} \\
(0.632)\end{array}$ & $\begin{array}{l}0.564^{*} \\
(0.34)\end{array}$ & $\begin{array}{c}-1.552^{*} \\
(0.88)\end{array}$ & $\begin{array}{l}-0.557 \\
(0.86)\end{array}$ & $\begin{array}{l}-0.098 \\
(0.49)\end{array}$ & $\begin{array}{c}0.39 \\
(0.25)\end{array}$ \\
\hline Constant & $\begin{array}{l}4.642^{*} \\
(2.70)\end{array}$ & $\begin{array}{c}0.507 \\
(1.443)\end{array}$ & $\begin{array}{l}4.014^{*} \\
(2.18)\end{array}$ & $\begin{array}{c}2.615^{* *} \\
(1.13)\end{array}$ & $\begin{array}{c}9.566^{* *} \\
(4.61)\end{array}$ & $\begin{array}{c}0.153 \\
(2.454)\end{array}$ & $\begin{array}{l}8.763^{*} \\
(4.773)\end{array}$ & $\begin{array}{c}7.229 * * * \\
(2.54)\end{array}$ & $\begin{array}{l}3.067 \\
(3.48)\end{array}$ & $\begin{array}{l}0.153 \\
(2.45)\end{array}$ & $\begin{array}{l}1.396 \\
(2.42)\end{array}$ & $\begin{array}{l}0.997 \\
(1.26)\end{array}$ \\
\hline
\end{tabular}

Notes: Values in parentheses are standard errors. ***, **, and * indicate statistical significance at the $1 \%, 5 \%$, and $10 \%$ levels, respectively. 


\section{Conclusion}

This study examined the stock market performance of Vietnamese firms in response to the CPTPP's approval on November 12, 2018, using firm-level stock price data covering all listed firms on both the HOSE and HNX markets. Based on an event study, we quantify the effects of the news of the CPTPP's signing on the returns of Vietnamese listed firms. Then, we link these abnormal returns to listed firms' characteristics.

First, we found that the CPTPP announcement tended to induce positive abnormal returns for firms listed on both the HOSE and HNX markets in Vietnam. However, our empirical results also showed considerable heterogeneity in the magnitude and speed of this impact. News about the CPTPP's signing seems to have had immediate positive impacts on HNX firms' returns, whereas we only observed a positive impact on HOSE firms' returns for the longer event window, $[-5 ;+5]$. Additionally, we found differing results regarding the link between listed firms' characteristics and abnormal returns, and the HOSE and HNX markets do not share the same findings. These different results are mainly due to different features of the two Vietnamese stock exchanges.

Second, we found that the potential positive impact of the CPTPP's approval on returns is difficult to observe at the sectoral level. On one hand, the announcement of the CРТPP is not associated with positive abnormal returns for Vietnamese listed firms that are classified as firms with and without exporting activity. This result is not consistent with Melitz's (2003) model of firms engaged in international trade, which shows that that larger and more export-oriented firms may experience larger market impacts following announcement of RTAs. On the other hand, when we group Vietnam's listed firms into ten industries, we cannot reject the null hypothesis of no abnormal returns. In conclusion, the lack of a link between news of the CPTPP's signing and the financial performance of Vietnam's listed firms in our sectoral analysis does not imply that Vietnam's participation in the CPTPP has not brought any financial profits to its stock markets. Instead, the expected impact of the CPTPP on firms' financial performance may be underestimated at the sectoral level owing to the short time span of the estimation. In this regard, our empirical findings suggest that the time it takes for the CPTPP to significantly affect Vietnamese listed firms' financial performance at the sectoral level remains an open question. In addition, this study only focuses on the immediate reactions of Vietnamese stock returns to the implementation of the CPTPP rather than on the long-run impact of this trade agreement on Vietnam's stock market performance. Thus, using a larger database to resolve the question of whether Vietnam's stock markets benefit from the CPTPP in the long run is an important challenge for our future research. 


\section{References}

Ahmada, S., \& Schroeder, R. (2003). The impact of human resource management practices on operational performance: Recognizing country and industry differences. Journal of Operations Management, 21, 19-43.

Boehmer, E., Musumeci, J., \& Poulsen, A. B. (1991). Event-study methodology under conditions of event-induced variance. Journal of Financial Economics, 30(2), 253-272.

Breinlich, H. (2014). Heterogeneous firm-level responses to trade liberalization: A test using stock price reactions. Journal of International Economics, 93, 270-285.

Breinlich, H. (2016). The effect of trade liberalization on firm-level profits: An event-study approach (LSE Research Online Documents on Economics 66412). London School of Economics and Political Science, LSE Library.

Brown, S., \& Warner, J. (1985). Using daily stock returns: The case of event studies. Journal of Financial Economics, 14(1), 3-31.

Bui, T. N. (2018). CPTPP Serving Vietnam as opportunities and challenges. Retrieved from https://modernd iplomacy.eu/2018/01/17/cptpp-serving-vietnam-opportunities-challenges/

Campbell, J., Lo, A., \& MacKinlay, A. C. (1997). The econometrics of financial markets. Princeton: Princeton University Press.

Cañón-de-Francia, J., \& Garcés-Ayerbe, C. (2009). ISO 14001 Environmental Certification: A sign valued by the market? Environmental and Resource Economics, 44(2), 245-262.

Corrado, C. (1989). A non-parametric test for abnormal security price performance in event studies. Journal of Financial Economics, 23(2), 385-395.

Crowley, M. A., Meng, N., \& Songe, H. (2019). Policy shocks and stock market returns: Evidence from Chinese solar panels. Journal of The Japanese and International Economies, 51, 148-169.

Dasgupta, S., Ho Hong, J., Laplante, B., \& Mamingi, N. (2006). Disclosure of environmental violations and stock market in the Republic of Korea. Ecological Economics, 58(4), 759-777.

Dür, A., \& Lechner, L. (2019). Who wins and who loses from trade agreements? Stock market reactions to news on TPP and TTIP (Paper prepared for presentation at the 12th Annual Conference on the Political Economy of International Organization). University of Salzburg, Austria, February 7-9.

Fama, E. F. (1970). Efficient capital markets: A review of the theory and empirical work. The Journal of Finance, 25(2), 383-417.

Fama, E. F., Fisher, L., Jensen, M. C., \& Roll, R. W. (1969). The adjustment of stock prices to new information. International Economic Review, 10(1), 1-21.

Ghani, W. I., \& Haverty, J. L. (1995). The impact of the North American Free Trade Agreement on multinational firms: Evidence from the stock market. Journal of International Accounting Auditing \& Taxation, 4(2), 163-173.

Gupta, S., \& Goldar, B. (2005). Do stock markets penalize environment-unfriendly behavior? Evidence from India. Ecological Economics, 52(1), 81-95.

Hendricks, K. B., \& Singhal, V. R. (2003). The effect of supply chain glitches on shareholder wealth. Journal of Operation Management, 21(5), 501-522. 
Hofmann, C., Osnago, A., \& Ruta, M. (2017). Horizontal depth: A new database on the content of preferential trade agreements (Policy Research Working Paper; no. WPS 7981). Washington, D.C.: World Bank Group.

Hopenhayn, H. (1992). Entry, exit, and firm dynamics in long run equilibrium. Econometrica, 60, 1127-1150.

Johnson, N. J. (1978). Modified t tests and confidence intervals for asymmetrical populations. Journal of American Statistics Association, 73(363), 536-544.

Kawai, M., \& Wignaraja, G. (2008). Regionalism as an engine of multilateralism: A case for a single East Asian FTA (Working Paper Series on Regional Economic Integration No. 14). ADB.

Klassen, R. D., \& McLaughlin, C. P. (1996). The impact of environmental management on firm performance. Management Sciences, 42(8), 1199-1214.

Krugman, P. R. (1980). Scale economies, product differentiation, and the pattern of trade. American Economic Review, 70, 950-959.

MacKinlay, A. C. (1997). Event studies in economics and finance. Journal of Economic Literature, 35(1), 13-39.

Maliszewska, M., Zoryana, O, \& Osorio-Rodarte, I. (2018). Economic and distributional impacts of comprehensive and progressive agreement for trans-pacific partnership: The case of Vietnam (English, Vietnamese). Washington, D.C.: World Bank Group.

McWilliams, A., \& Siegel, D. (1997). Event studies in management research: theoretical and empirical issues. Academy of Management Journal, 40(3), 626-658.

Melitz, M. J. (2003). The impact of trade on intra-industry reallocations and aggregate industry productivity. Econometrica, 71(6), 1695-1725.

Moser, C., \& Rose, A. K. (2014). Who benefits from regional trade agreements? The view from the stock market. European Economic Review, 68, 31-47.

Nezerwe, Y., \& Karangwa, A. (2018). Did the Morocco stock market benefit from the free trade agreement with the US? Transnational Corporations Review, 10(2), 161-169.

Nguyen, M. (2018). The CPTPP is not just TPP version 2.0. Retrieved from https://www.vir.com.vn/the-cpt pp-is-not-just-tpp-version-20-57064.html

Parinduri, R. A., \& Thangavelu, S. M. (2013). Trade liberalization, free trade agreements, and the value of firms: Stock market evidence from Singapore. The Journal of International Trade \& Economic Development, 22(6), 924-941.

Qian, P. Y., \& Diaz, J. F. (2017). Volatility integration of global stock markets with the Malaysian stock market: A multivariate GARCH approach. Malaysian Journal of Economic Studies, 54, 83.

Ravenscraft, D. J. (1983). Structure-profit relationships at the line of business and industry level. Review of Economics and Statistics, 65, 22-31.

Ries, J. C. (1993). Windfall profits and vertical relationships: who gained in the Japanese auto industry from VERs? Journal of Industrial Economics, 41(3), 259-276.

Rodriguez, P. (2003). Investor expectations and the North American Free Trade Agreement. Review of International Economics, 11(1), 206-218.

Sharpe, W. (1964). Capital asset prices: a theory of market equilibrium under conditions of risk. Journal 
of Finance, 19(3), 425-442.

Thompson, A. J. (1993). The anticipated sectoral adjustment to the Canada-United States Free Trade Agreement: An event study analysis. Canadian Journal of Economics, 26(2), 253-271.

Thompson, A. J. (1994). Trade liberalization, comparative advantage, and scale economies Stock market evidence from Canada. Journal of International Economics, 37(1), 1-27.

Trefler, D. (2004). The long and short of the Canada-U.S. free trade agreement. American Economics Review, 94, 870-895.

Wiklund, J., \& Shepherd, D. (2003). Knowledge-based resources, entrepreneurial orientation, and the performance of small and medium-sized businesses. Strategic Management Journal, 24(13), 1307-1314. 